\title{
Characterization and Degradation of Masonry Mortar in Historic Brick Structures
}

\author{
Denis A. Brosnan \\ Clemson University, 100 Clemson Research Boulevard, Anderson, SC 29625, USA \\ Correspondence should be addressed to Denis A. Brosnan; bdenis@clemson.edu
}

Received 7 January 2014; Revised 16 March 2014; Accepted 18 March 2014; Published 27 April 2014

Academic Editor: Elio Sacco

Copyright (C) 2014 Denis A. Brosnan. This is an open access article distributed under the Creative Commons Attribution License, which permits unrestricted use, distribution, and reproduction in any medium, provided the original work is properly cited.

\begin{abstract}
This study characterized mortars from a masonry fortification in Charleston, South Carolina (USA), harbor where construction was during the period 1839-1860. This location for analysis was interesting because of the sea water impingement on the structure. The study was included as part of an overall structural assessment with restoration as an objective. The mortars were found to be cement, lime, and sand mixtures in proportions similar to ones expected from the historic literature, that is, one part binder to two parts of sand. The binder was found to be American natural cement, a substance analogous to the European Roman cement. The results suggest that the thermal history of the cement during manufacturing affected setting rate explaining why the cements were considered as variable during the mid-to-late 1800s. Fine pores were found in mortars exposed to sea water resulting from corrosion. Contemporary natural cement was shown to release calcium in aqueous solution. While this release of calcium is necessary for setting in natural and Portland cements, excessive calcium solution, as exacerbated by sea water contact and repointing with Portland cement mortars, was shown to result in brick scaling or decay through cryptoflorescence.
\end{abstract}

\section{Introduction}

Assessments of historic masonry structures include precise documentation of dimensions and elevations, analysis of structural stability, and characterization of materials. The characterization is a prerequisite to restoration and repair to insure that compatible materials are used and to protect the historic character of the structure.

Masonry mortars throughout history have been composed of a binder material, aggregates, and additions, the latter of which alter the properties of the mortar during application or enhance properties in the hardened condition. The binders developed through history include natural pozzolanic materials (as used by Greek and Roman societies), lime and hydraulic lime, Roman cements (called natural cement when manufactured in the USA), and Portland cement. The historical development of binders is presented in detail by Blezard [1], von Landsberg [2], Eckel [3], and Cummings [4]. Elsen [5] provides comprehensive references on binders. Weber et al. [6] describe Roman cements in Europe with characterization of mortars by chemical analysis and petrography. Callebaut et al. [7] used advanced analytical techniques in mortar characterizations.

Aggregates for masonry mortars are generally described as "fine" to distinguish the larger aggregate particles and stones used in concrete. The fine aggregates include crushed rock and natural sands with national specifications published in modern times for aggregate gradation [5]. Other substances found in historic mortars include ashes, brick fragments or other ceramics particles, and natural fibers.

Until the advent of specifications on mortar materials or properties of hardened mortar, masons mixed fine materials or binders with aggregates in volumetric proportions to obtain acceptable consistencies of fabrication of masonry structures. In contemporary language, these proportions along with water content provided consistency for troweling.

The focus of this paper is on the application of advanced analytical techniques to supplement traditional analyses in characterizing masonry mortars in a selected historic structure, Fort Sumter National Monument located in Charleston, South Carolina (USA), harbor. A second purpose is determining if microscopic evidence exists for physical and 
TABLE 1: Chemical analysis of Rosendale cement.

\begin{tabular}{|c|c|c|c|c|c|}
\hline Species & $\begin{array}{c}\text { Historic reference } 1 \\
{[10]}\end{array}$ & $\begin{array}{c}\text { Historic reference } 2 \\
{[11]}\end{array}$ & $\begin{array}{c}\text { Modern Rosendale } \\
{[12]}\end{array}$ & $\begin{array}{c}\text { Contemporary } \\
\text { Rosendale }\end{array}$ & $\begin{array}{c}\text { Insoluble residue, } \\
\text { contemporary Rosendale }\end{array}$ \\
\hline $\mathrm{CaO}$ & 27.8 & $33-60$ & 35.3 & 46.3 & 1.1 \\
\hline $\mathrm{MgO}$ & & $12-21$ & 19.2 & 22.8 & 0.3 \\
\hline $\mathrm{Al}_{2} \mathrm{O}_{3}$ & 5.5 & $5.5-10$ & 5.5 & 4.3 & 8.3 \\
\hline $\mathrm{SiO}_{2}$ & 27.8 & $27-33$ & 34.2 & 23.0 & 84.0 \\
\hline $\mathrm{Fe}_{2} \mathrm{O}_{3}$ & 4.3 & & 2.6 & 1.8 & 1.5 \\
\hline $\mathrm{TiO}_{2}$ & & & 0.3 & 0.1 & 0.2 \\
\hline $\mathrm{Na}_{2} \mathrm{O}$ & & & 0.5 & 0 & 1.6 \\
\hline $\mathrm{K}_{2} \mathrm{O}$ & & & 2.2 & 1.8 & 2.9 \\
\hline Sum of constituents & & & 99.8 & 100.1 & 99.9 \\
\hline $\begin{array}{l}\text { Cementation index } \\
\text { (CI) }\end{array}$ & & & 1.66 & 0.90 & \\
\hline
\end{tabular}

chemical alteration of the mortars through corrosion and/or mineral alteration.

Fort Sumter is a "Third System" USA fortification built on a sand bar in Charleston harbor with construction starting in 1829. The Fort's construction began with careful placement of large granite blocks forming a peripheral foundation on the sand bar. After infill of the area encircled by the granite blocks with shells and sand, the brick wall construction began in 1841 using the materials and design principles dictated by General Joseph Gilbert Totten, Chief Engineer of the United States Army $[8,9]$. As a young man, Totten studied use of Roman cements in Europe, and he subsequently specified use of the American analog to Roman cement, both known as "natural cement" and "Rosendale cement" in the USA.

General Totten's representatives typically specified Lawrence's Rosendale Cement for bedding mortar. Totten's mortar recipes were typically one part of cement to two parts of sand by volume. Acknowledging that the cement was a costly component when delivered at distant sites from New York, Totten states "It appears that when cement mortars are not required to be the strongest that can be made-a little lime may be added without great loss of tenacity, and, of course, with a saving of expense." Totten allowed the use of a cement-lime-sand mortar of respective volumetric proportions $2: 1: 6$.

\section{Materials and Methods}

Mortar specimens were obtained by removing bricks from the outermost wythe of bricks, that is, facing bricks, from the structure so as to obtain bedding mortar materials. All mortar materials were selected from the Eastern "Gorge Wall," of the Fort that was rebuilt in the 1870 s after substantial damage due to bombardment during the American Civil War. Care was taken to exclude any Portland cement pointing mortars applied to some sections of the exterior walls in the 1960s. For analysis purposes, a specimen of Rosendale cement was obtained from the current manufacturer, Edison Coatings, with that analysis being reported in Table 1.
The techniques used in this mortar analysis are well known and conform to the literature citations provided. As cited earlier, Elsen published a review paper on the microscopy of historic mortars [5]. Krotzer and Walsh describe acid digestion techniques, instrumental analysis, and imaging techniques using polarized light microscopy [13]. The acid digestion techniques are described in standard methods [14]. Chiari et al. have used thermal analysis, a technique identifying weight changes and heat flow within materials during heating, to analyze historic mortars [15]. Brosnan et al. used combined techniques including chemical and mineralogical analysis, petrography, and thermal analysis to arrive at mortar compositions [16].

\section{Results and Discussion}

3.1. Cement Characterization. Cementitious materials are typically characterized by their chemical analysis or "assay" using constituents identified as metal oxide species per the convention employed by cement chemists. The analyses of Rosendale natural cement are shown in Table 1. It is clear that oxides of calcium, magnesium, aluminum, silicon, and iron are the major constituents of the cement. Walsh and Uracius point out that the Rosendale cement is manufactured by burning/heating of argillaceous (clay containing) limestone [17].

Natural cement was burned or "calcined" in periodic and continuous kilns so that it would "set," that is, exhibit hydraulic activity, when ground and mixed with water. Mineral identification techniques including X-ray diffraction show that contemporary Rosendale cement contains major constituent minerals of anorthite-a calcium aluminosilicate (38.2\%), quartz (28.7\%), and microcline-a potassium aluminosilicate (12.6\%). The familiar compounds in Portland cement are also present including alite-tricalcium silicate $(6.4 \%)$ and belite-dicalcium silicate (4.0\%). The content of amorphous phase and unidentified phases was $10.1 \%$.

These constituent minerals imply that a "set condition" (hardening) is attained after mixing cement with water 


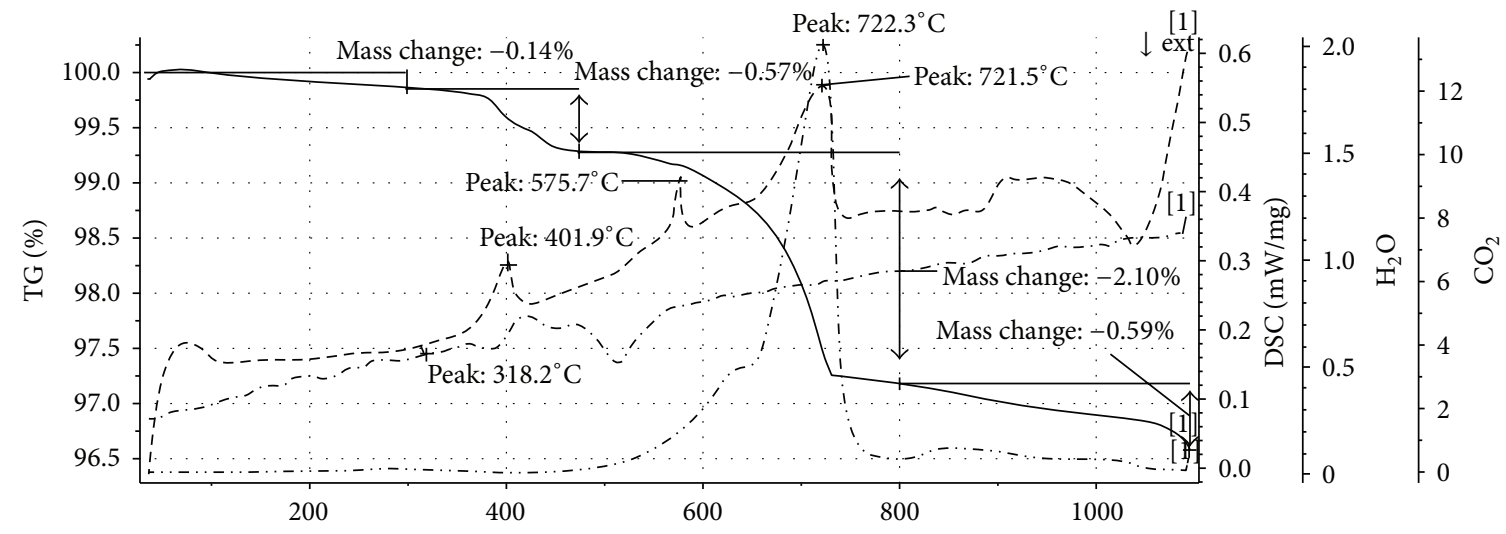

[1] Rosendale cement 4 August 2010.dsu

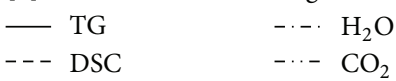

FIGURE 1: Thermal analysis of contemporary Rosendale cement. (TG: thermogravimetric trace, DSC: differential scanning calorimeter trace, water: water evolution trace, and $\mathrm{CO}_{2}$ : carbon dioxide evolution trace).

through early carbonation of some compounds plus formation of calcium silicate phases. The cements can be compared on the basis of a cementation index (CI), the latter as delineated by Boynton [18], as follows:

$$
\mathrm{CI}=\frac{\left(2.8 \times \% \mathrm{SiO}_{2}+1.1 \times \% \mathrm{Al}_{2} \mathrm{O}_{3}+0.7 \times \% \mathrm{Fe}_{2} \mathrm{O}_{3}\right)}{(\% \mathrm{CaO}+1.4 \times \% \mathrm{MgO})}
$$

The cementation index (CI) for modern Rosendale (Table 1) of 1.66 is similar to the value of 1.65 reported by Weber for Roman cement. The variation in cementation index is apparently a characteristic of American natural cement. While results in historic references may be due to older analytical procedures, it is known that the American natural cements were highly variable in setting characteristics, and this fact has been attributed to their eventual demise.

The thermal analysis of ground natural cement is shown in Figure 1. This figure contains several results on the same graph making a careful inspection necessary.

The thermal analysis provides the following important information:

(1) low temperature cement dehydration occurs below $500^{\circ} \mathrm{C}$ implying that the as-ground cement exhibits a content of phases normally expected in set cement after use; that is, there has been some formation of compounds during the cement in manufacture (as in grinding) and during storage prior to use. These phases may include carbonates and sulfates of the cement constituents;

(2) the cement exhibits an endothermic/heat absorbing reaction at $575^{\circ} \mathrm{C}$ reflecting the presence of quartz "sand" in the cement rock (see also the insoluble residue analysis in Table 1);

(3) the cement exhibits a major decomposition of calcium carbonate at $722^{\circ} \mathrm{C}$ verifying that the cement was burned to an intermediate temperature between the decomposition temperature of magnesium carbonate, a constituent of dolomitic limestone in cement rock, and that of calcium carbonate also present in the cement rock.

The fact that there is partial decomposition of the cement rock in manufacturing American natural cement strongly suggests that the setting characteristics of the cement are influenced by its thermal history. This is another reason for the consideration of historic natural cement as a variable product.

The natural cement was additionally characterized by its release of soluble materials when placed in water suspension at room temperature (typically for 20 hours). The cement released about 15,000 parts per million (ppm) or 1.5\% (by unit weight of cement) of calcium ions when 100 grams of cement was placed in $100 \mathrm{~mL}$ of deionized water at $20^{\circ} \mathrm{C}$ for 24 hours. The solution of potassium was particularly significant at $1357 \mathrm{ppm}$ reflecting the argillaceous nature of the limestone. Another notable release of soluble material was sulfate at about $5000 \mathrm{ppm}$, and the decomposition of sulfates may explain the weight loss in the cement below $500^{\circ} \mathrm{C}$ (Figure 1). The release of soluble metals such as calcium and potassium provides credence to the idea that the initial set/hardening of the cement, in part, is due to atmospheric carbonation processes and the formation of sulfates.

3.2. Mortar Characterization. Mortar analysis included determination of physical properties, chemical and mineralogical analysis, and microscopic examinations. Five mortar specimens were examined with three of the specimens obtained from positions above the mean high tide level and two from below ground or mean high tide level. The physical properties of the mortars are shown 
TABLE 2: Physical properties of mortar specimens (total mortar of binder and aggregate).

\begin{tabular}{lccccc}
\hline Specimen & $\begin{array}{c}\text { Number 5 bedding } \\
\text { mortar above sea level }\end{array}$ & $\begin{array}{c}\text { Number 6 pointing } \\
\text { mortar above sea level }\end{array}$ & $\begin{array}{c}\text { Number 11 bedding } \\
\text { mortar above sea level }\end{array}$ & $\begin{array}{c}\text { Number 3 bedding } \\
\text { mortar below sea level }\end{array}$ & $\begin{array}{c}\text { Number 15 building, } \\
\text { below infill soil level }\end{array}$ \\
\hline $\begin{array}{l}\text { Bulk density, } \mathrm{Mg} / \mathrm{m}^{3} \\
\text { Apparent porosity, \% }\end{array}$ & 1.32 & 1.23 & 1.62 & 1.73 & 1.81 \\
$\begin{array}{l}\text { Percentage of porosity } \\
<1 \text { micron in diameter }\end{array}$ & 44.1 & 43.1 & 31.6 & 24.3 & 22.7 \\
\hline
\end{tabular}

TABLE 3: Chemical analyses and other data for Fort Sumter mortars (total mortar of binder and aggregate).

\begin{tabular}{|c|c|c|c|c|c|}
\hline Specimen & $\begin{array}{c}\text { Number } 5 \text { bedding } \\
\text { mortar above sea } \\
\text { level }\end{array}$ & $\begin{array}{l}\text { Number } 6 \text { pointing } \\
\text { mortar above sea sevel }\end{array}$ & $\begin{array}{c}\text { Number } 11 \text { bedding } \\
\text { mortar above sea } \\
\text { level }\end{array}$ & $\begin{array}{l}\text { Number } 3 \text { bedding } \\
\text { mortar below sea level }\end{array}$ & $\begin{array}{l}\text { Number } 15 \text { building, } \\
\text { below infill soil level }\end{array}$ \\
\hline $\mathrm{CaO}$ & 0.73 & 54.57 & 12.30 & 0.74 & 26.79 \\
\hline $\mathrm{MgO}$ & 9.20 & 15.53 & 5.05 & 0.72 & 11.59 \\
\hline $\mathrm{Al}_{2} \mathrm{O}_{3}$ & 1.21 & 2.84 & 0.96 & 1.75 & 2.00 \\
\hline $\mathrm{SiO}_{2}$ (Total) & 82.63 & 22.11 & 80.28 & 88.33 & 57.73 \\
\hline $\mathrm{Fe}_{2} \mathrm{O}_{3}$ & 4.31 & 1.94 & 1.76 & 5.11 & 1.83 \\
\hline $\mathrm{TiO}_{2}$ & 1.25 & 0.15 & $<0.02$ & 1.67 & 0.06 \\
\hline $\mathrm{Na}_{2} \mathrm{O}$ & $<0.50$ & 1.02 & $<0.50$ & $<0.50$ & $<0.50$ \\
\hline $\mathrm{K}_{2} \mathrm{O}$ & 0.70 & 1.83 & 0.14 & 1.68 & $<0.05$ \\
\hline Sum of constituents & 100.03 & 99.99 & 100.49 & 100.00 & 100.00 \\
\hline Insoluble residue, \% & 60.74 & 16.20 & 76.48 & 65.21 & 48.15 \\
\hline XRD mineralogy & $\begin{array}{l}\text { Calcite, quartz, } \\
\text { sodalite }\end{array}$ & Calcite, quartz & $\begin{array}{l}\text { Calcite, quartz, } \\
\text { sylvite }\end{array}$ & $\begin{array}{c}\text { Calcite, quartz, } \\
\text { iowaite, bassanite, } \\
\text { brucite }\end{array}$ & $\begin{array}{l}\text { Calcite, quartz, } \\
\text { epidote }\end{array}$ \\
\hline $\begin{array}{l}\text { Soluble sodium or } \mathrm{Na} \\
\text { (ppm of solids) }\end{array}$ & 839 & 2092 & 149 & 2066 & 851 \\
\hline $\begin{array}{l}\text { Soluble calcium or } \mathrm{Ca} \\
\text { (ppm of solids) }\end{array}$ & 3752 & 513 & 918 & 1807 & 3184 \\
\hline $\begin{array}{l}\text { Soluble chloride or } \mathrm{Cl} \\
\text { (ppm of solids) }\end{array}$ & 1232 & 2706 & 148 & 5801 & 7406 \\
\hline $\begin{array}{l}\text { Soluble sulfate or } \mathrm{SO}_{4} \\
\text { (ppm of solids) }\end{array}$ & 7218 & 1555 & 509 & 824 & 350 \\
\hline $\begin{array}{l}\text { Rough mix } \\
\text { proportions by } \\
\text { volume } \\
\text { cement : lime: sand }\end{array}$ & $1: 2: 4$ & $1: 2 \frac{1}{2}: \frac{1}{4}$ & $1: 4: 9$ & ND & $1: 3.5: 3$ \\
\hline
\end{tabular}

in Table 2. All measurements were made using mercury intrusion porosimetry (MIP) because of the small size of the specimens. In MIP, mercury is forced into the pores of the specimen under pressure allowing for a calculation of the amount of porosity (apparent porosity) and for a calculation of the pore sizes present in the specimen.

The differences in density and apparent porosity of mortar likely reflect the local construction practices of the time. Lower bulk density and higher porosity usually reflect high water content in the mortar. The differences in density and porosity may reflect the rapid reconstruction of the Fort during an era of increased international tensions.

It is interesting that the submerged mortars, constantly exposed to sea or ground salts, exhibit near normal porosity values, but they exhibit a significantly larger fraction of "fine" pores, that is, those less than one micron in diameter. Mortars above mean high tide level exhibit near normal porosities with no elevation in fraction of fine pores. The data suggests that salt water corrosion results in very high fractions of fine pores in fully or frequently submerged specimens.

The chemical analyses by XRF and other data for the mortar specimens are shown in Table 3 with one specimen analyzed per position on the Fort. For specimens not exposed to sea water, the magnesium oxide $(\mathrm{MgO})$ content is a first suggestion that the mortars contained natural cement. Two of the mortars (numbers 3 and 5) exhibited very low calcium oxide $(\mathrm{CaO})$ suggesting extreme solution of calcium from the mortar in sea water.

All of the mortars exhibited water soluble species at room temperature. The mortars with low residual $\mathrm{CaO}$ 


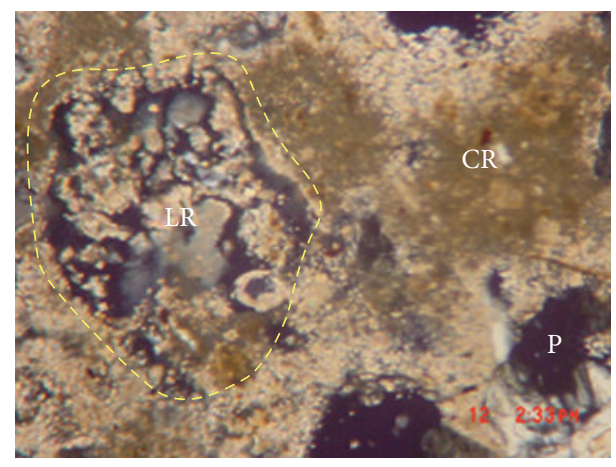

FIgure 2: Typical mortar photomicrograph (ca. 150x).

content (numbers 3 and 5) exhibit high soluble sodium content (mortar 15 was exposed to ground salts, and the solution was exacerbated by salt water infiltration). Most mortars exhibited new mineral salts formed during service by salt water exposure (sodalite, sylvite, iowaite, bassanite, and epidote). Lubelli et al. [19] link chloride and sulfate in salt water to the solution of calcium from the mortars. This provides a likely reason for reduced $\mathrm{CaO}$ in some of the mortars at Fort Sumter.

Petrographic analysis using polarized light microscopy confirmed the presence of Rosendale cement in the historic mortars. A typical photomicrograph is shown in Figure 2 where a Rosendale cement relic (indicated as CR) is shown in the field with a lime relic (LR) and porosity (P) in a carbonate matrix. Scanning electron microscopy with energy dispersive $\mathrm{X}$-ray analysis confirmed the phase identifications.

All mortars contained silica sand typically exhibiting greater than $96 \% \mathrm{SiO}_{2}$ when examined using scanning electron microscopy. The variation in $\mathrm{CaO}$ content in Table 3 , a consequence of leaching by sea water of the lime phase, results in an effect of the value of the total analysis for $\mathrm{SiO}_{2}$ in the mortars.

The rough mix proportions were determined using the insoluble residue as the aggregate content of the mortar, and the lime content was calculated using thermogravimetric data for each mortar (weight loss at the calcium carbonate decomposition). The balance was considered as the cement content. The volumetric proportions were calculated from standard densities for constituents per ASTM C1324. The proportions of the mortars (Table 3 ) at least are conceptually similar to the Totten formula of one part of fine material (cement and lime) to two parts of sand. All of the bedding mortars exhibit a greater volumetric proportion of sand to fines. The rough mix proportions (Table 3 ) do not match the Totten formula exactly, and this was likely a consequence of local construction practices. The pointing mortar contains less sand than the bedding mortars as expected.

3.3. Structural Observations. One very interesting finding was salt scaling on the exterior walls of the Fort where there had been pointing repairs with ordinary Portland cement mortar (Figure 3). This is a classic case of "brick scaling" caused by excessive solution of calcium from the repair

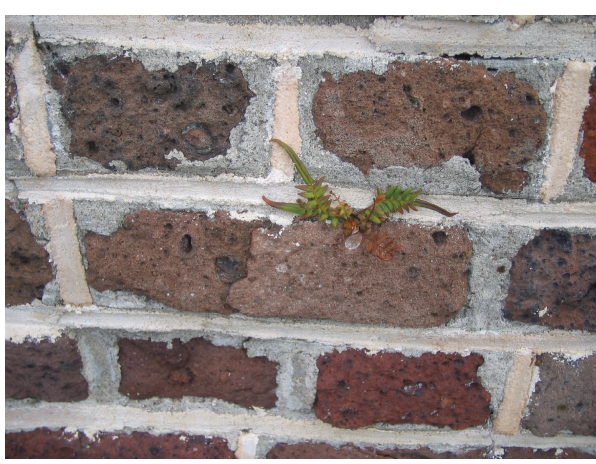

FIgURE 3: Salt scaling on the lower Fort walls pointed with Portland cement mortar.

mortar in the presence of sea salts as explained by Lubelli et al. [19]. The results suggest that the Portland cement mortar was a source of sufficient soluble calcium to cause the damage. Similar scaling failures are not seen on areas of the Fort that have not experienced repointing with Portland cement mortar.

Such scaling is technically known as cryptoflorescence, and the scaling is due to subsurface expansions within the bricks via salt crystallization. Thus, cryptoflorescence is a damaging mechanism to the historic materials, while surface discolorations known as efflorescence are a nondamaging cosmetic defect in masonry.

A cryptoflorescence failure on the Fort is shown together with scanning electron microscope photomicrographs in Figure 4. On this face of the Fort, the Portland cement pointing mortar used in modern repairs has completely worn away revealing the "pink" colored Rosendale cement-based bedding mortar. The effect of the calcium solution from repair mortar and infiltration into the bricks with moisture is evident in the "cupped shape" of the residual brick. The scanning electron microscope investigation identified the mineral phase ettringite near the periphery of the brick. It is well known that the formation on ettringite results in expansive forces. This expansion resulted in damage to the historic bricks as shown in the photograph.

\section{Conclusions}

Use of natural or Rosendale cement was confirmed as a constituent of the mortars by a combination of traditional and advanced analytical techniques. The advanced techniques provide rapid and complimentary results so that the mortar constituents are identified for restoration purposes. Further, mortar batch compositions were similar to those expected from the historical record.

The sea salt exposure produced characteristic fine pores within the mortar reflecting calcium removal via corrosion. Calcium removal also resulted in salt scaling or cryptoflorescence on the masonry walls as seen on brick surfaces. It is important that structural analysts recognize salt scaling on bricks and its possible causation in excessive calcium solution from masonry mortar. 

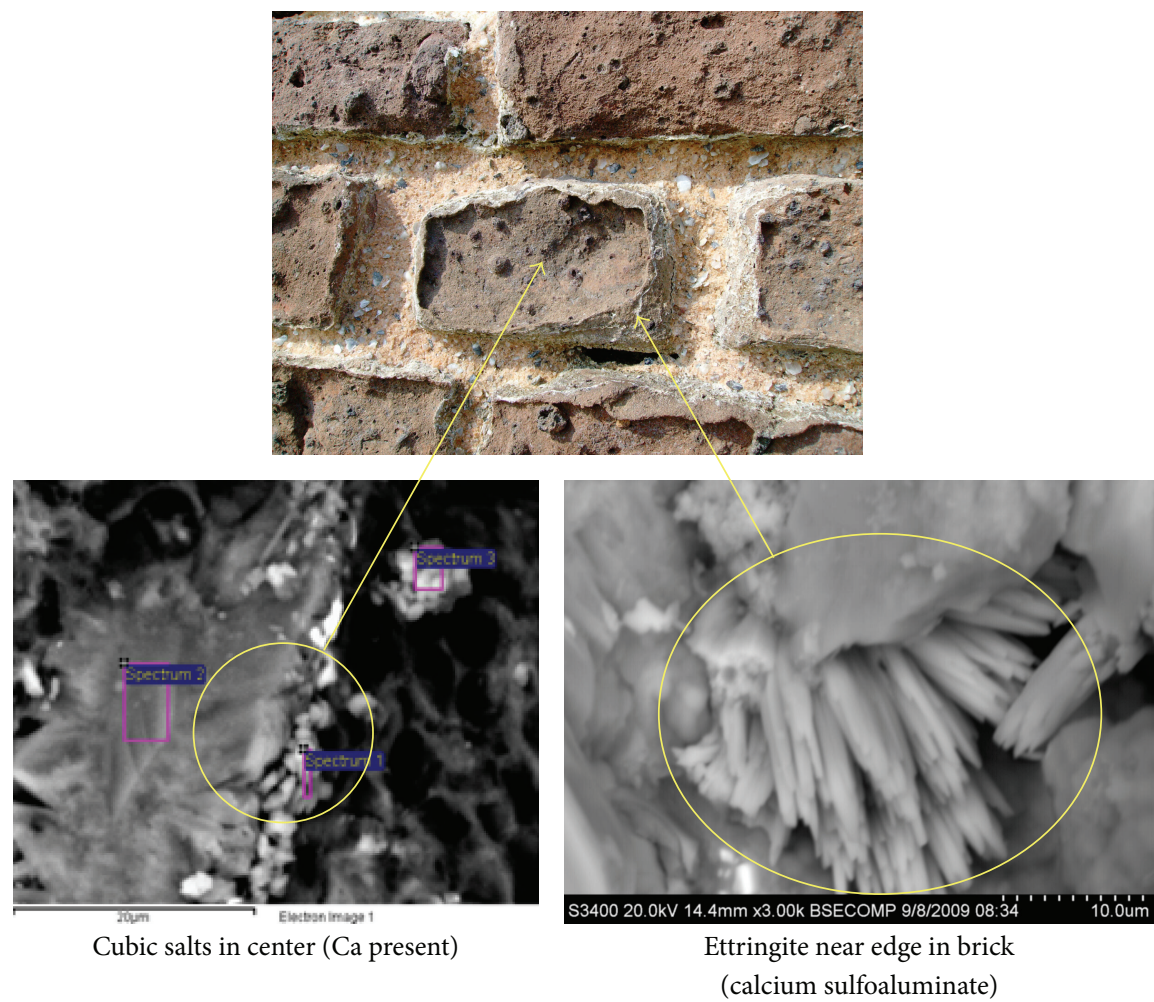

FIGURE 4: Cryptoflorescence failures on Fort Sumter: macroscopic and microscopic (SEM) results.

\section{Conflict of Interests}

The author declares that there is no conflict of interests regarding the publication of this paper.

\section{References}

[1] R. G. Blezard, The History of Calcerous Cements, Lea's Chemistry of Cement and Concrete, Elsevier, 4th edition, 1998.

[2] D. von Landsberg, "The history of lime production and use from early times to the industrial revolution," Zement-Kalk-Gips, vol. 8, pp. 192-203, 1992.

[3] E. C. Eckel, Cements, Limes, and Plasters-Their Materials, Manufacture, and Properties, Donhead Publishing, 2005.

[4] U. Cummings, American Cements, Natural Binders Press, 2006, Edited by D. Chapman.

[5] J. Elsen, "Microscopy of historic mortars-a review," Cement and Concrete Research, vol. 36, no. 8, pp. 1416-1424, 2006.

[6] J. Weber, N. Gadermayr, K. Buyar et al., "Roman cement mortars in Europe's architectural heritage of the 19th century," Journal of ASTM International, vol. 4, pp. 69-83, 2007.

[7] K. Callebaut, J. Elsen, K. Van Balen, and W. Viaene, "Nineteenth century hydraulic restoration mortars in the Saint Michael's Church (Leuven, Belgium): natural hydraulic lime or cement?" Cement and Concrete Research, vol. 31, no. 3, pp. 397-403, 2001.

[8] R. Horres, "The Building of Fort Sumter," Presented at the Charleston Museum, May 2011.

[9] J. G. Totten, Essays on Hydraulic Lime and Common Mortar and on Lime Burning, Translated from the French with 1825 to 1838, Lt. Col. of Eng. and Brevet Co., 1838, M. P. Edison, Section 5,
Brief Observations on Common Mortars, Hydraulic Mortars, and Concretes, with Some Experiments Made Therewith at Fort Adams, Newport Harbour, Natural Cement, R. I. FROM ASTM STP, 1494, 2007.

[10] A. Rogers and J. Alexander, Industrial Chemistry, 3rd edition, 1920.

[11] B. Arthur, "On the composition of ancient cements and Rosendale cements," Journal of the Franklin Institute, vol. 95, no. 3, pp. 204-210, 1873.

[12] R. Vyskocilova, W. Schwarz, D. Mucha, D. Hughes, R. Kozlowski, and J. Weber, "Hydration processes in pastes of roman and American natural cements," ASTM STP, vol. 4, no. 2, 2007.

[13] D. E. Krotzer and J. J. Walsh, "Analyzing mortars and stuccos at the college of Charleston: a comprehensive approach," $A P T$ Bulletin, vol. 40, no. 1, pp. 41-48, 2009.

[14] ASTM International, Standard Test Method for Examination and Analysis of Hardened Masonry Mortar, vol. 2005 of ASTM C1324-05, ASTM International.

[15] G. Chiari, G. Torraca, and M. Santarelli, "Recommendations for systematic instrumental analysis of ancient mortars: the Italian experience, Standards for Preservation and Rehabilitation," ASTM STP, vol. 1258, pp. 275-284, 1996.

[16] D. A. Brosnan, J. P. Sanders, and S. A. Hart, "Application of thermal analysis in preservation and restoration of historic masonry materials-part A: Characterization of materials," Journal of Thermal Analysis and Calorimetry, vol. 106, no. 1, pp. 109-115, 2011.

[17] J. Walsh and K. Uracius, "Exploring American natural cement rock from its national distribution to its chemistry and 
microstructure," in Proceedings of the 1st American Natural Cement Conference, 2005.

[18] R. S. Boynton, Chemistry and Technology of Lime and Limestone, Wiley, New York, NY, USA, 1989.

[19] B. Lubelli, R. P. J. van Hees, and C. J. W. P. Groot, "The role of sea salts in the occurrence of different damage mechanisms and decay patterns on brick masonry," Construction and Building Materials, vol. 18, no. 2, pp. 119-124, 2004. 

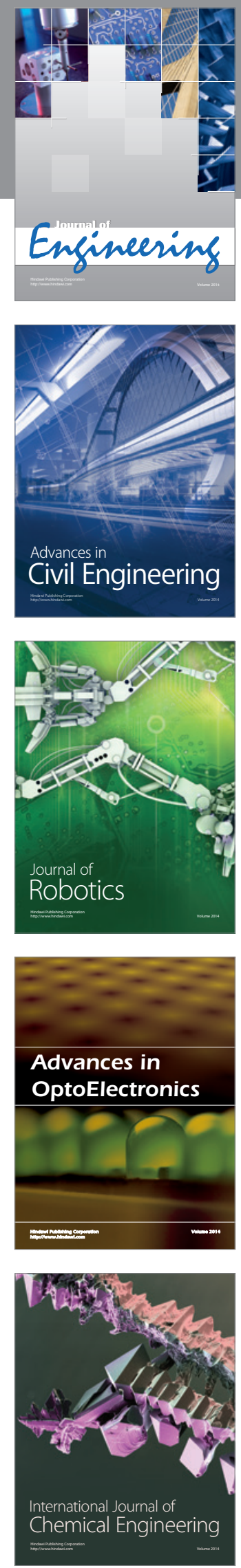

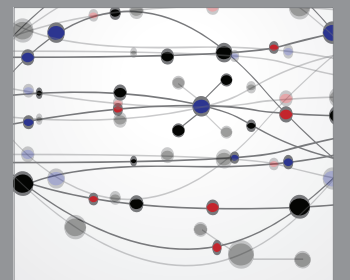

The Scientific World Journal
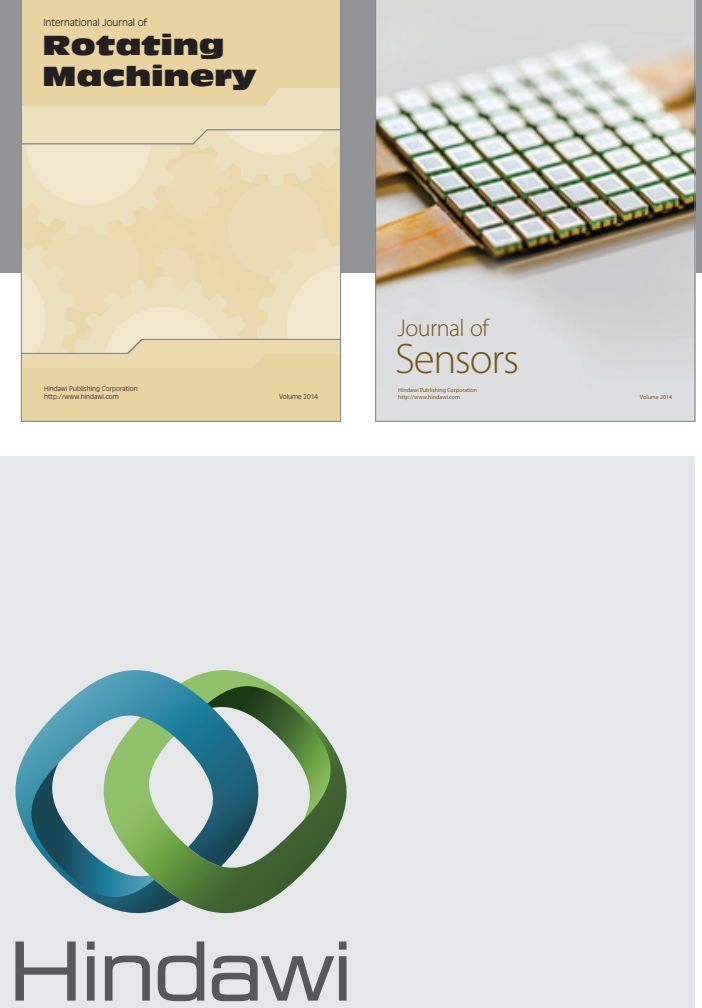

Submit your manuscripts at http://www.hindawi.com
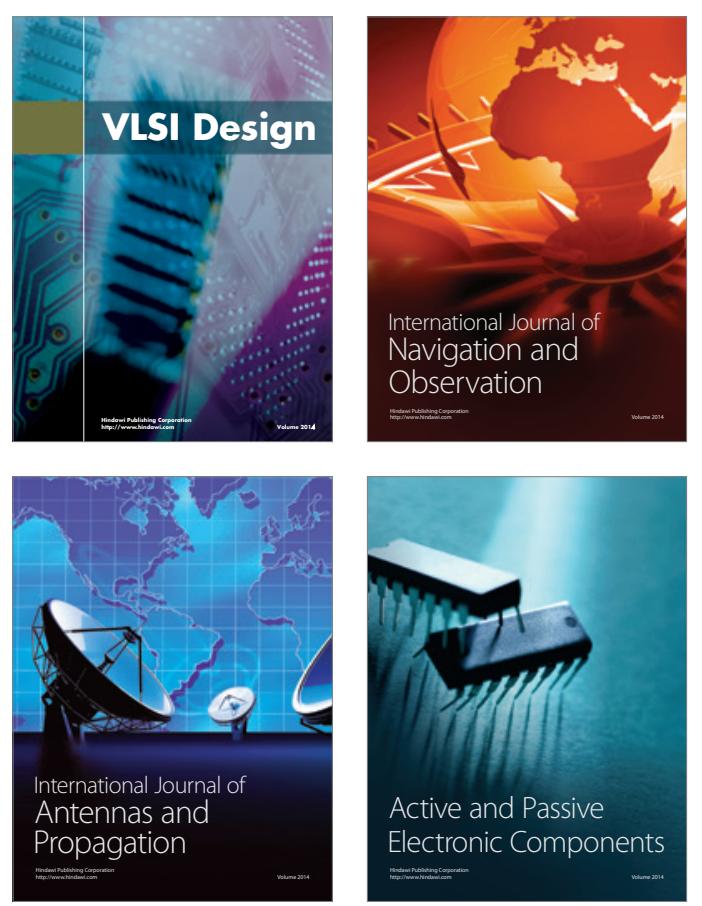
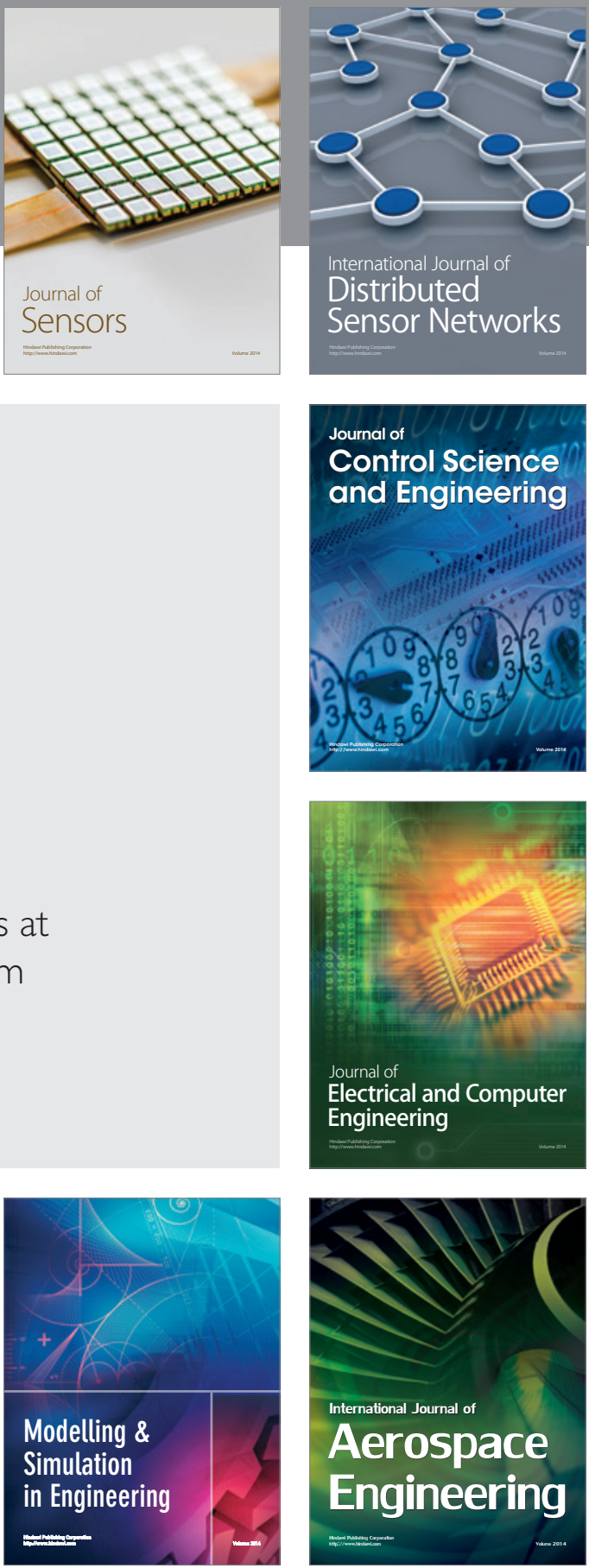

Journal of

Control Science

and Engineering
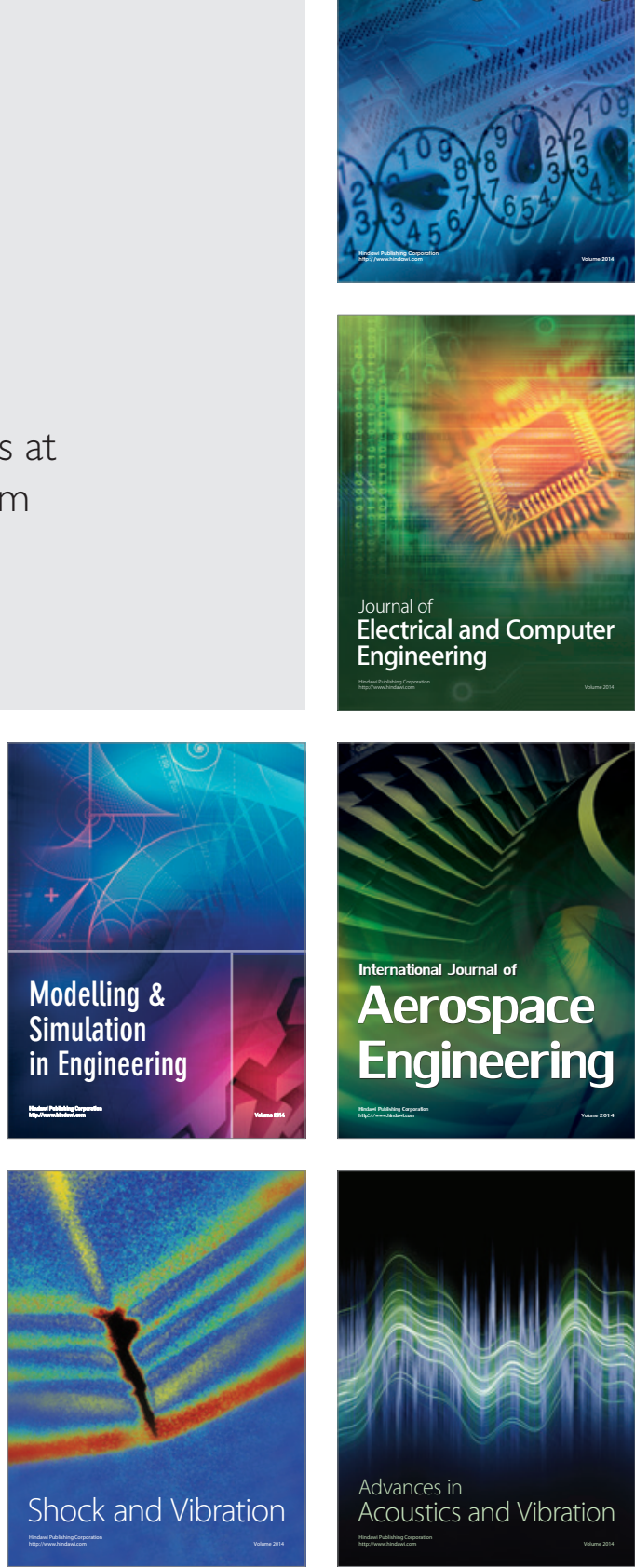